\title{
A celebratory turning alone to Wentzel van Huyssteen: An academic appreciation
}

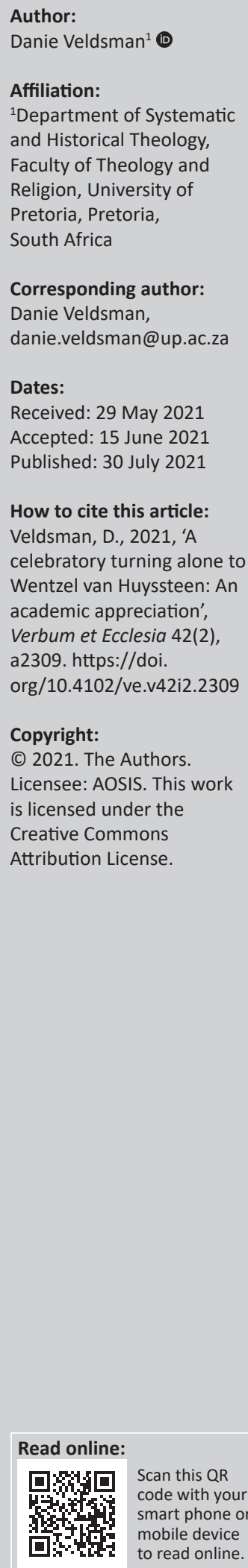

In appreciative celebration of Van Huyssteen's contribution as international pattern-setter for the theology-science dialogue and especially on the nature of theological reflection and rationality, the article focuses specifically on the South African context and three contributions that Van Huyssteen made in engagement with Johan Heyns over a period of almost four decades. From his critical commentary on the Heyns/Jonker (1977) book publication Op weg met die Teologie through his Teologie as Kritiese Geloofsverantwoording (Van Huyssteen 1986) to his delivering of the Johan Heyns Memorial Lecture (2016), the two key theologicalmethodological issues that he consistently addressed were truth and progress. Van Huyssteen's basic concern throughout his academic career was on why the theologian would try to speak publicly, and the ever accompanying question on who would care to hear his voice. In critical engagement from a South African context with Van Huyssteen's answer to the question that he poses, it is argued that Van Huyssteen in his very sophisticated post-foundational approach, characterised by contextuality and transversality, ultimately does not methodologically take care of the constitutive interdisciplinary significance of affectivity of embodied persons in our publicly cognitive sensemaking of our respective lifeworlds, deeply characterised by pluriversality.

Intradisciplinary and/or interdisciplinary implications: The article explores and critically discusses the initial Critical-Realistic approach that later developed into a postfoundational approach by Wentzel van Huyssteen. The discussion is consciously restricted to his South African publications and covers the fields of the philosophy of science, systematic theology, philosophy and evolutionary theology within contemporary sciencetheology discourses.

Keywords: Wentzel van Huyssteen; post-foundationalism; theology-science dialogue; transversality; contextuality; pluriversality; religious experience.

\section{Just another poor (theological) boy?}

\author{
His public meetings were a danger to the state, \\ Some soldier said 'Who was he anyway?' \\ (From 'Spanish Train', Chris de Burgh) \\ Why would the theologian try to speak publicly? And who would care to hear his voice? \\ (From: Heyns Memorial Lecture, Wentzel van Huyssteen 2017:2)
}

In the first year class of Biblical Studies in 1978 at the University of Port Elizabeth, South Africa sat an enthusiastic 18-year-old student who just started his journey with theological studies, eagerly looking forward to the educational road travelled by many before him. However, before the class stood a young 36-year-old enthusiastic lecturer who would accompany the students on that very road, but who was surprisingly to take the students on a science of philosophy road not yet theologically travelled within the South African context. The dress code for students at that time was formal. It was therefore not out of place for the lecturer to ask the student, dressed in a tracksuit, what his explanation could be for simply ignoring the dress code. The explanation was brief, stating that his dream was to play squash for the university team, and that squash practices started at four and the classes only finished at four. He did not want to miss out on any one of the two. The lecturer kindly responded that it was in order, but on the condition that the student would henceforth also play squash on a regular basis with the lecturer who was very eager to play better squash. If only the lecturer's squash was as good as his lectures! That very condition was not only met for the next three years, but developed far beyond the initial enforcement. It evolved

Note: Special Collection: Festschrift for Wentzel van Huyssteen. 
into a life-time friendship and occasional squash games over a period of more than 10 years. Just more than three decades later, in September 2013, the lecturer was to present his final teaching term as James I McCord Professor of Theology and Science at Princeton Theological Seminary (1992-2014), crowning a period of distinguished international contributions to the methodological-theological road within the theology-science dialogue and on the nature of rationality. In his class sat the student, now a Visiting Scholar as academic to the seminary, dressed (again) in his tracksuit and attending his final set of lectures in appreciative acknowledgement of a very special person and teacher (see Figure 1). That teacher was Wentzel van Huyssteen. I had the privilege to be that student (and also to have played squash for the University of Port Elizabeth).

It is therefore a wonderful occasion for me to celebrate in this Festschrift the distinguished contribution of Van Huyssteen as international pattern-setter for the theology-science dialogue, and especially on the nature of theological reflection and rationality. I therefore turn 'alone' to him in this academic celebratory appreciation. Two other impressive Festschriften have already been dedicated to Van Huyssteen, namely The Evolution of Rationality (2006) and Human Origins and the Image of God (2017). The former Festschrift was edited by the American theologian Leron Shults, professor of theology at Agder University College in Kristiansand, Norway. He was a doctoral student of Van Huyssteen. The latter Festschrift was edited by Christopher Lilley and Daniel Pedersen. Lilley was at the time of publication a $\mathrm{PhD}$ student at Marquette University (Milwaukee, Wisconsin), whereas Pedersen earlier completed his PhD at Princeton Theological Seminary. Both publications consist of an impressive wideranging contribution of scholars. Altogether, there are 37 contributions, but with only two contributions from South African scholars. ${ }^{1}$

It is therefore academically appropriate that the specific South African engagement with Van Huyssteen's internationally acclaimed contribution should also be remembered, re-visited, and celebrated. In what follows, I will focus specifically on what I see as the most enduring contribution of Van Huyssteen to the South African theological context. Apart from De Villiers and Smit who were the only two South African theologians approached to contribute to the second Festschrift dedicated to Van Huyssteen, a number of South African scholars over the years have responded to and engaged with Van Huyssteen since his publication in Koers (Van Huyssteen 1978) on the question: What is theology, and what does the nature of

1.The two contributions were from Dirk Smit (then at the University of Stellenbosch and currently with Princeton Theological Seminary, USA) and Etienne de Villiers (emeritus professor from the University of Pretoria). Smit engaged in his contribution with Van Huyssteen on the construction of ethical discourses. According to Smit, ethical problems were seldom central to any of Van Huyssteen's writings, although morality was always implicit in his focus on questions concerning rationality, humanity and being human. In turn, De Villiers explored in his contribution the relation between Van Huyssteen's postfoundationalist approach and his ow approach to the ethics of responsibility, arguing that proponents of the postfoundationlist approach ought to be sympathetic to the ethic of responsibility approach.

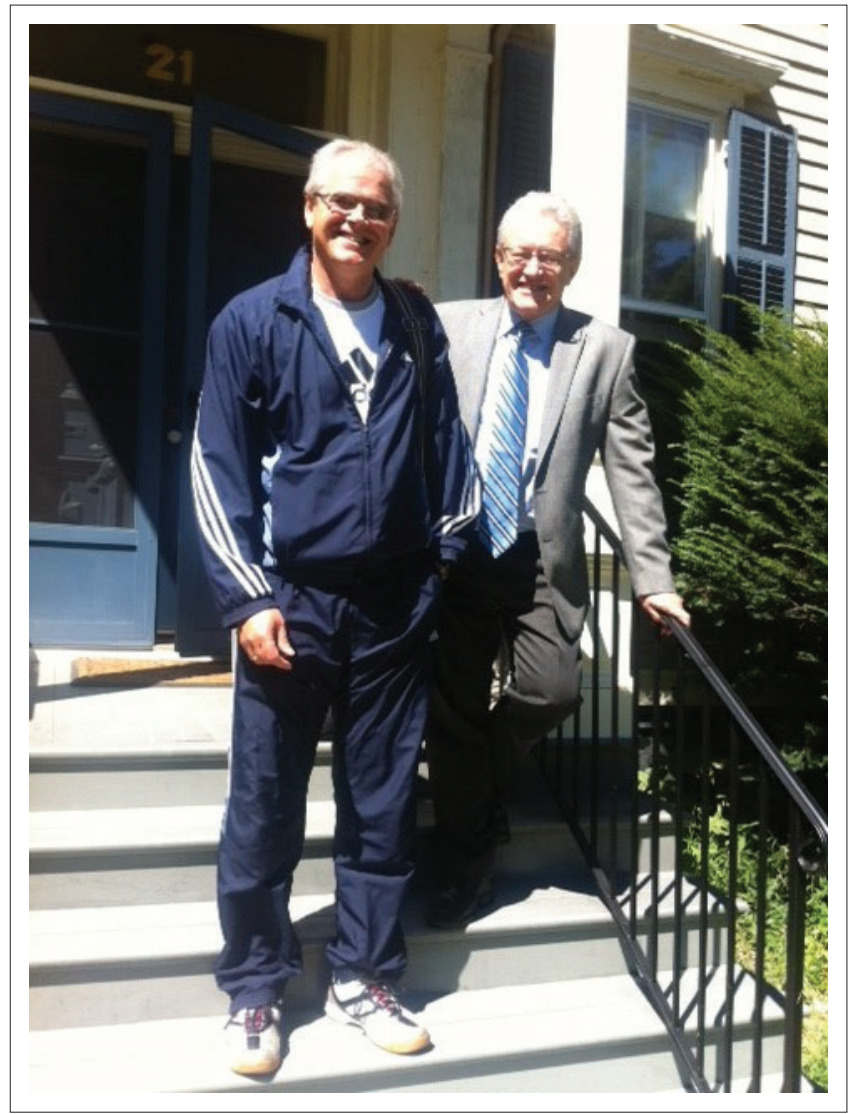

FIGURE 1: Prof. Van Huyssteen and myself - in tracksuit! - just before we left his house for the first class of his final term at Princeton Theological Seminary in September 2013

theological reflection and rationality entails? ${ }^{2}$ In my specific contribution, I would like to focus mainly on the Van Huyssteen-Heyns interaction with reference to a few other South African scholars. ${ }^{3}$ My restricted focus will fall firstly on Van Huyssteen's article publication (1978a) in which he engages critically with the book publication by Heyns/ Jonker. Secondly, I will turn (read: jump) to the Heyns Memorial Lecture 4 delivered 38 years later at the Faculty of Theology and Religion, University of Pretoria by Van Huyssteen, then emeritus professor of Princeton theological Seminary and residing in Cape Town, South Africa. My jump will be bridged and preceded by his most important South African publication, namely Teologie as Kritiese $e^{4}$ Geloofsverantwoording that was published four years before he left for Princeton. Finally, I will summarise what I deem to be the most important academic legacy of Van Huyssteen, responding to my initial quoted questions posed by Van

2.Since his first Afrikaans article in 1969 on Pannenberg (1969), namely "Die geskiedenisteologie van Wolfhart Pannenberg', NGTT 10(4) 1969, Van Huyssteen published four more articles before his publication in Koers in 1978. All the articles related to the question on the nature of theological reflection, methodology and truth. See his 'God en Werklikheid', NGTT 14 (1973); 'Hoe waar is ons teologiese uitsprake?', Bulletin van die SAVCW (1973); 'Gesag en Vryheid in Bybelse Perspektief', Roeping en Riglyne (1974); 'Bybelkunde, Teologie en die Bybel', NGTT 15 (1975) During this period he read his inaugural address 'Wat is Bybelkunde?' at the University of Port Elizabeth in 1974. Another eight Afrikaans article publications followed before his book publication in 1986 of Teologie as kritiese geloofsverantwoording. That represents his last publication in Afrikaans.

3.No effort will be made here in what follows to give a comprehensive overview of Van Huyssteen's theological contribution. I have done that elsewhere in an earlier publication (cf. Veldsman 2008)

4.Published a year later as "Is there any hope for "truth" and "progress" in theological thinking today?' (Van Huyssteen 2017). 
Huyssteen himself: Why would the theologian try to speak publicly? And who would care to hear his voice? My response will clearly show - in playful reference to the quote from Chris de Burgh's Spanish Train - that he is definitely not just another poor (theological) boy!

\section{The initial finding of direction in the South African context: Van Huyssteen in Koers and on Op weg met die Teologie}

My wordplay in English in the title to this section on the name of the first South African journal Koers (English: Direction) in which Van Huyssteen engages with the publication $O p$ weg met die Teologie (English: On Course with Theology) of the two Stellenbosch theologians Johan Heyns and Willie Jonker, is rather forced. ${ }^{5}$ The wordplay on 'koers' and 'op weg' is delightful in Afrikaans, but rather boring when executed in English. Van Huyssteen's seminal publication in 1978 explored and directed a promising and very original understanding of theological reflection in reaction to the 'first' Afrikaans book publication $O p$ weg on theological methodology and encyclopedia. ${ }^{6}$ However, his explorative directive was applauded as well as criticised. What was the core of his original explorative directive? It was to take the contemporary questioning within the science of philosophy on the grounding and methods of scientific reflection seriously for the sake of the integrity, credibility and truth of theological reflection and (progressive) statements.

Van Huyssteen (1978a:377ff.) neatly captures the metatheoretical questioning ${ }^{7}$ in the following clear formulations: what is theology; what is the nature, extent and trustworthiness of theological statements; how can these statements be grounded and justified? The problem that spontaneously arises for theological reflection relates to its exclusive and unique claim regarding the object of its reflection. That object is God's revelation that we find in scripture. This very claim puts theological reflection in strict opposition to other fields that have to justify the grounding of their respective presuppositions for making reliable and trustworthy statements. To critically address the claim, Van Huyssteen (1978a:381ff.) turns to the book publication Op weg met die Teologie (1977) that was published four years earlier, and reprinted in 1977. It was the first South African publication in Afrikaans according to Van Huyssteen that 5.At the time of publication, they were systematic theologians at the University of
Stellenbosch. Shortly after the publication, Heyns accepted a calling in 1974 to the Faculty of Theology at the University of Pretoria.

6.This however was not the case. A year earlier, namely in 1973, the Afrikaans book Inleiding in die Teologie was published by NG Kerkboekhandel. The publication was edited by three theologians from UNISA: I.H. Eybers, A. König and J.A. Stoop. Another Afrikaans publication Sistematiese Teologie (1975) by the Lutheran theologian Klaus Nürnberger from Natal also preceded Van Huyssteen's article. The first section of the book by Nürnberger discusses theological methodology - and back then he already pleaded for a broadening of theological interaction with othe disciplines, especially the natural sciences. Because it was not taken up in the main disciplines, especially the natural sciences. Because it was not taken up in the main stream of Afrikaans theological publications at that time, it remained fairly unknown for a very long period of time. Only after the publication of Heyns' Dogmatiek that became more widely known and the status of the first publication was corrected.

7.Meta-theoretical questioning entails the reflective unfolding of the question 'what is theology' by means of its grounding and justification of its statements. took the question of the scientific nature of theological reflection seriously. ${ }^{8}$ He criticises the defended position by Heyns/Jonker, which he labels scriptural theology ('Skrifteologie') that seeks to interpret the inspired scriptures truly, taking the reality of grace and justification bestowed on fallen, sinful humanity as vantage point. Such a theological approach unfolds within the space between revelation and faith with as object God's revelation and scriptural proofs as method of justification. Although Heyns/Jonker argue that theological reflection share in the contemporary developments within science of philosophy and should not isolate itself, and that theological reflection should methodologically avoid subjectivism, Van Huyssteen argues and unmasks the discrepancies in their viewpoint. Ultimately, Van Huyssteen argues that theology as science for Heyns/Jonker represents scientific reflection with a unique character and unique rationality - simply because the structure of revelation and the subsequent faith response, embedded in the personal commitment of the theologian, ensures its truth and validity. That - for Van Huyssteen (1978a:387ff.) - is to completely immunise and isolate theological reflection. He poses the fundamental question to them, 'How can we after all be assured that you have succeeded to "have" revelation as your vantage point and has not actually only succeeded to present your subjective presentation of God and God's revelation?' And the very danger of subjectivism that you passionately seek to avoid is now neatly, faithfully and methodologically disguised in your viewpoint. No, we cannot overcome the isolation of theological reflection if it takes as vantage point an understanding of revelation that stems from the personal faith commitment of the theologian, and that subsequently acts as uncritical vantage point for all theological reflection and statements to follow. And to rub questioning salt into such a view point, Van Huyssteen (1978:394) concludes that it has been precisely the intense hermeneutical developments over the last few years that has convincingly shown that because of the hermeneutical gap and distance between us and the historical origin of the texts, as well as the narrative manner in which these texts come to us, we cannot simply uncritically take and hold scriptural theology for making 'true' statements. Methodological and reflective acknowledgement of these very hermeneutical developments, will - according to Van Huyssteen (1978:395) bring the object of our reflective efforts sharper and more credible into focus as we engage with the contemporary developments within the science of philosophy.

Ironically, the chief editor of the journal Koers requested König, one of the authors of the book Inleiding in die Teologie to review Van Huyssteen's article. Van Huyssteen was not aware of their book mentioning Op weg met die Teologie as the first Afrikaans publication on methodology. In reality, it was not like that. However, to Van Huyssteen's defence, it must be added that it was not a complete book on theological methodology, but only a brief chapter of 18 pages on the

$8 . S e e$ footnote 6 on the correction regarding his remark on 'the first Afrikaans' publication. 
subject. In his contribution on theological methodology as introduction to the book, entitled Die Teologiese Wetenskap, König (cf. 1978:403ff.), the theologian from UNISA, holds very much of the same viewpoint as presented in the year later publication by Heyns/Jonker. In his response to Van Huyssteen, however, he strangely agrees with the criticism of Van Huyssteen on Heyns/Jonker. He does remark that it is possible that he misunderstands Van Huyssteen - which is indeed the case with regard to his critical remarks on Van Huyssteen - who, according to him, simply presents his own convictions in the same authoritarian manner as those who he criticises. In this sense, Van Huyssteen, according to König, now falls into the row of Barth - Heyns - Van Huyssteen. What clearly exposes König's misunderstanding of Van Huysteen is his remark that he thinks Van Huyssteen is turning a practical matter into a matter of principle. In his friendly response, Van Huyssteen (1978b) indicates the questions posed by König which he (Van Huyssteen) does not understand. He repeats the core of his argument, namely that in theological reflection on methodology, the moment of subjectivity must methodologically be justified in its responsibility towards rationality from the first reflective step. And this very step Van Huyssteen reflectively takes on himself impressively in his book publication Teologie as Kritiese Geloofsverantwoording on the nature of theological reflection. In my academic opinion, the text represents not only the fundamental basis and framework for his academic career and contribution to follow, but also the intellectual bridge between his first publication in Afrikaans on Heyns and the Heyns Memorial Lecture, 38 years later at the University of Pretoria.

\section{The literary-argumentative bridge: Teologie as Kritiese Geloofsverantwoording}

Eight years after his first engagement with Heyns on the nature of theological reflection, Van Huyssteen published his Teologie as Kritiese Geloofsverantwoording (Van Huyssteen 1986) ${ }^{9}$ with the subtitle, Teorievorming in die Sistematiese Teologie. ${ }^{10}$ It represented only the second publication in the series Raad vir Geesteswetenskaplike Navorsing (RGN)studies in Navorsingsmetodologie of which Johann Mouton was the series editor. In 1989, it was translated and published in English as Theology and the Justification of Faith. ${ }^{11}$

For Van Huyssteen, the most pressing theological question in the South African context of that time was whether theology

9.See the critical reviews of his book by J.S. Kruger (1987) in Theologica Evangelica 20(1), 64-70 and A.A. van Niekerk (1986) in the South African Journal of Philosophy 5(3). A number of other South African scholars critically engaged with Van Huyssteen's publication: D.J. Smit (1988), 'Theology as a critical account of personal faith', in: Mouton, J., Van Aarde, A.G., Vorster, W.S. (eds.), Paradigms and Progress in Theology, pp. 91-112, HSRC, Pretoria; D.F.M. Strauss (1991) 'Wat is teologie?' Tydskrif vir Christelike Wetenskap 27(2), 1-22; A.A. van Niekerk (1992) Rasionaliteit en Relativisme, RGN, Pretoria; Jaco Kruger (1997) 'Epistemiese waardes in die rasionaliteitsmodel van Wentzel van Huyssteen', Koers 62(1), 29-44.

10.At the evening function on the 28 February 1986 of the launch of the book, Van Huyssteen recalls a remark by Johan Heyns who asked him, 'Wentzel, so when are you going to start to do proper Systematic Theology?

11.In the discussion that follow of his book, I will make use of references from the English translation. I also rely for this section on my overview of the work of Van Huyssteen that was published in Scriptura 98 (2008), 222-230. can still speak out contextually in such a manner that the liberating voice of the gospel may be heard loudly and clearly in all facets of our society (cf. Van Huyssteen 1989:x). He pursued to answer the question in a commitment to experiential and epistemological adequacy by developing a model of rationality which can be characterised as a 'weak' form of Critical Realism (CR). Crucial to the model that he developed was the methodological guiding question whether theological reflection can be considered 'rational in any significant sense, particularly when compared with the apparent rigor of the natural sciences'. Van Huyssteen (1989:x-xviii) argued that if theology was a 'critical account rendering of faith' that strives for relevance in the world, then theologians cannot evade the methodological, hermeneutical and epistemological issues that precede the forming of theological propositions.

As theologian, he subsequently does not evade the issues and constructively address them in his Teologie as Kritiese Geloofsverantwoording. He firstly turns to a critique of logical positivism, unmasking its ideological character and refuting its methodological (positivistic) smugness which left - by implication - all metaphysical-theological statements as cognitively meaningless. For the unmasking and refutation of positivism, Van Huyssteen finds his philosophical ammunition in the socio-historical (Popper) and contextual (Kuhn) nature of scientific discovery and Larry Laudan's argument for a relative progress in science (Van Huyssteen 1989:24ff.; 47ff.; 173ff.). Although they posed their very own challenges for theological reflection (which he simultaneously addresses in a rigorous dissection of the theological designs of Barth, Heyns, Bartley, Pannenberg and Sauter, see 11ff., 19ff., 33ff., 71ff. and 101ff.), Van Huyssteen tackled them by starting - in dialogical interaction amongst others (e.g. Ernan McMullan, see page 148ff., 188, 195ff.; Sallie McFague, see page $73 \mathrm{ff} ., 131 \mathrm{ff} ., 104 \mathrm{ff} ., 163 \mathrm{ff}$.$) with interdisciplinary$ theology-science theoreticians (e.g. Peacocke, see page 156ff.) - to develop a set of minimal criteria for a credible model of theological rationality (Van Huyssteen 1989:143ff.). He now explicitly identifies the problem of rationality as an essentially epistemological problem, believing that the 'epistemological dimension must form the very foundation of all further methodological and thus also of all hermeneutical questions in theology' (Van Huyssteen 1989:xii), and his own position as a critical realist. In his own words:

A critical realist stand is realistic because in the process of theological theorising, this concept enables us to recognise this cognitive and referential nature of analogical languages as a form of indirect speech. However, it is also critical, because the role of metaphoric language in theology would teach us that models should never be absolutised or ideologised, but should retain their openness and provisionality throughout the process of theorising. (p. 142)

In developing his set of criteria (reality depicting, problemsolving ability, progressive, see page 146ff.) for a credible Christian theology, he focuses on the origin of theological theories, and from there, on religious experience and religious 
language, concluding that they work together in the conceptualising of theological models (Van Huyssteen 1989:125ff.). For his developing model of rationality, it simply implied that theological reflection had to be aware of the limits of religious language (i.e. its metaphorical nature, see page 126ff., 132ff.) and on how their contextual faith commitments shaped their reasoning. He captures the fundamental thrust of his viewpoint with the insightful formulation, stating that our metaphoric articulation of our beliefs and the conceptual organisation thereof, find expression in our theological models. His acknowledgement of the unavoidable and shaping role of contextual faith commitments (see page 159ff.) did not imply the negation of commitments, but rather that they could reach out responsibly across contextual borders and make valid, yet provisional inter-subjective theological statements in addressing conceptual and empirical problems. For these statements to be considered rational, the theologian had to engage both the theological reflective sources (the Bible, tradition, dogma and creedal formation, see page $177 \mathrm{ff}$.) as well as contemporary scientific thought (see page 186ff.). And progress thus meant the ability of a theory to effectively answer the addressed theological problems (see page 190ff.). In this manner, Van Huyssteen argumentatively moves in his commitment to experiential and epistemological adequacy of theological reflection from being a 'non-foundationalist' (i.e. searching for a non-fideist rational basis) to a 'post-foundationalist'.

How is his subsequent evolved and intellectually matured 'post-foundationalist' viewpoint to be understood more than 38 years later in the Heyns' Memorial Lecture - and after teaching 23 years at Princeton Theological Seminary?

\section{The Heyns' Memorial Lecture (2016): Now proclaiming publicly the open (interdisciplinary) road to be travelled}

Van Huyssteen formulated the title of his Heyns' Memorial Lecture as question: Is there any hope for truth and progress in theological thinking today $?^{12}$ It is the very question - now sharply rephrased - on theology as a science that Van Huyssteen pursued from his first engagement with Heyns on truth and the nature of theological reflection to the eventual intellectual unfolding of his post-foundational approach, that is, theological reflection as interdisciplinary rational activity. ${ }^{13}$ In his now deeply matured and

12.To formulate the title of prominent publications as questions became a trademark of Van Huyssteen's subsequent contributions. See as examples: Scientific Realism and Theology: A New Challenge? (1987); Paradigms and Progress: Inference to the Best Explanations? (1988); Narrative Theology: An Adequate Paradigm for Theological Reflection? (1989); Theology and Science: Should the Church Really Care? (1993): Critical Realism and God: Can There Be Faith After Foundationalism? (1993); Should We Be Trying So Hard to Be Postmodern? (1997); What Are Scientists Telling Theologians About Human Uniqueness? (2001); Falling Angels or Rising Beasts? (2003); Alone in the World? (2006).

13.Van Huyssteen's basic critical conviction and directive for all of his theologicalmethodological explorations over his intellectual career was that the content and methodology of theology could never be deduced from the 'truth of revelation' itself, but instead should be shaped by a general theory of science. However, what is important in his lecture is the manner in which truth is now qualified. sophisticated post-foundational approach, ${ }^{14}$ he has reworked, revised and broadened his set of criteria (reality depicting, problem-solving ability, progressive) for a credible Christian theology that he proposed in his Teologie as Kritiese Geloofsverantwoording. His set of criteria is revised, reworked and broadened from insights from evolutionary epistemology, the evolutionary history of becoming human and being human (especially the role of language and imagination), and ultimately from exciting new developments - such as niche construction - from post-Darwinian evolutionary reflections. ${ }^{15}$ Through his reworking, revising and broadening, he transcends the traditional boundaries of theological, philosophical and social reflection, establishing an intellectual context of theology as a deeply cultural and contextual venture (cf. Van Huyssteen 2017:1). It is a venture that he addresses from the self-critical questions, namely 'Why would the theologian try to speak publicly? And who would care to hear his (sic) voice?' (Van Huyssteen 2017:2). This is what I wanted to capture in the preceding title formulation for this section on Van Huyssteen, namely 'Now proclaiming publicly the open (interdisciplinary) road to be travelled'. At the same time, I wanted to connect it closely in continuity and discontinuity with his initial teaching at the University of Port Elizabeth that we as students back then experienced as a methodological 'road less travelled' (see page 1). ${ }^{16}$

The 'open' and ever broadening road that Van Huyssteen now 'proclaims' is an interdisciplinary journey that leaves behind the earlier unavoidable direct collision course between theological reflection, embedded in self-proclaimed (superior) rational strategies of immunisation on the one hand, and (arrogant) scientific reflection that held that it was the only (methodological) way to true knowledge - and also that there were no real limits to the competence of science. Van Huyssteen argues for an interdisciplinary dialogue that takes seriously the contextual, social and historical dimensions of both the sciences and religion, that is, a multidimensional approach. Such an approach implies that any interdisciplinary dialogue between the sciences and theological reflection should not only be grounded in contextual and historical studies of the actual practices of scientific and religious belief, but also focus on the actual real-life scientists or theologians who are venturing forth into the unknown and risky waters of such a dialogue (cf. Van Huyssteen 2017:2). In such an approach, the key terms for Van Huyssteen are 'transversality' and 'contextuality'. Why specifically these terms? Because they will enable us - he argues - to identify shared concerns and points of agreement on our interdisciplinary journey. At the same time, they will

14.The Heyns Memorial Lecture in 2016, two years after his retirement from Princeton Theological Seminary, was preceded 12 years earlier by the prestigious Gifford Lectures that was published in 2007 as Alone in the World? Van Huyssteen is up to this point the only South African theologian who has presented the famous annual Gifford Lectures. For that matter, he is also the first and only Princetonian thus far to have done so!

15.Most of this work was performed in his presentation of the Gifford Lectures in 2004.

16.Van Huyssteen (2017:2) explicitly acknowledges the decisive influence that the Heyns/Jonker publication of Op weg met die Teologie had on his critical development of his own interdisciplinary theology. According to him, Heyns 'certainly inspired' the radical turn in his own theological journey. He adds that he could never find himself in Heyns' brand of Reformed Theology and Neo-Calvinist philosophy, but it was, however, 'still the best thing around at the time'. 
expose areas of disagreement and direct possibilities for discussing divisive issues. Three important moves, however, are implied for theological reflection (cf. Van Huyssteen 2017:3ff.), namely: (1) the acknowledgement of the radical contextuality of all our intellectual work, the epistemically crucial role of interpreted experience, and the way that disciplinary traditions shape the values that inform our reflection about God and what we believe to be God's presence in the world (cf. Van Huyssteen 2017:3); (2) the opening of our (shared) rational eyes to an epistemic obligation that points beyond the boundaries of our own discipline, our local communities, groups, or cultures, towards plausible forms of interdisciplinary dialogue (cf. Van Huyssteen 2017:3) and (3) to embrace transversality, that is, the recognition and identification of our shared rational resources in different modes of knowledge that enable interdisciplinary dialogue - but most importantly, to help us to reach beyond the (porous) boundaries of our own traditional disciplines. For Van Huyssteen (2017:3), transversal reasoning promotes different, non-hierarchical but equally legitimate ways of viewing specific topics, problems, traditions, or disciplines, and creates the kind of space where different voices need not always be in contradiction, or in danger of assimilating one another, but are in fact dynamically interactive with one another.

How can these three important movements within Van Huyssteen's post-foundational approach be elucidated?

Debating and talking about rationality - and for that matter, about 'theology and science' - in any generic, abstract sense was no longer plausible. The radical social and historical contextuality of all our embodied rational reflection reveals that in our interdisciplinary dialogue, we should be concretely focused. That is, focused on specific theologians, specific kinds of theologies, and on their specific interaction with specific scientists from specific sciences on clearly defined and shared problems (cf. Van Huyssteen 2016:9), because all our embodied rational reflection springs from the shared resources of human rationality. It enables us - according to Van Huyssteen (2017:9) - to 'leave behind abstract, overgeneralised "blue-prints" for engaging in interdisciplinary research and helps us to focus on developing, first contextually, and then transversally, the merits of specific interdisciplinary problems' and 'reveals not only a more holistic, embodied way to think about human rationality, but also argues for the public voice of theology in our rather complex contemporary culture'.

It is the very acknowledgement of the shared resources of rationality that empowers scientists and theologians to argue for the rational integrity of their own specific disciplines whilst at the same time be free to pursue overlapping concerns, identify shared problems, and even parallel research trajectories as they cross disciplinary lines in multi-disciplinary research (Van Huyssteen 2017:9). But there is an even bigger intellectual reward that can flow from this post-foundational fountain, namely that in my/our particular disciplinary tradition, we can come across issues, problems and challenges that cannot be resolved by my / our resources alone. For Van Huyssteen (2017:10), it is exactly this kind of interdisciplinary awareness that may lead us to cross-disciplinary boundaries and reach out for intellectual support to other disciplines. Transversality - as he calls it - par excellence!

It is the very awareness and reaching out, and thus the methodological acknowledgement of the multi-dimensional, transversal nature of human rationality that makes it possible for us to engage with the pluralist, interdisciplinary conversation according to Van Huyssteen. However, an important structural and methodological enhancement now forms an integral part of the scientific integrity of the reflective process. It is an engagement across disciplinary boundaries with our full personal convictions intact, whilst at the same time it entails a theoretical empowerment to step beyond the limitations and boundaries of our own contexts, traditions, and disciplines (cf. Van Huyssteen 2017). Insightfully and forcefully, Van Huyssteen (2017:10) concludes:

It is in this sense that, in the dialogue between theology and other disciplines, transversal reasoning facilitates different, but equally legitimate ways of evaluating issues, problems, traditions, or even disciplines themselves. Transversal rationality thus emerges as a performative praxis where our multiple beliefs and practices, our habits of thought and attitudes, our prejudices and judgements, converge. (p. 10)

The emerged performative practice - as described above enables us to retain the language of epistemology by fusing it with hermeneutical concerns, and the subsequent convergence unfolds as a practical, embodied skill that 'enables us to gather and bind together the patterns of our daily experiences, and then make sense of them through communal, interactive dialogue' (Van Huyssteen 2014:10). This is the basis for Van Huyssteen (cf. 2017:10) on which Christian Theology can claim a public or democratic presence in interdisciplinary dialogue that ultimately imply that no one disciplinary voice, and no one set of judgements, practices, or principles, will be able to claim any absolute priority over, or be foundational for any other.

How then can Van Huyssteen's post-foundational approach and the subsequent implicated public presence of Christian theological reflection within the South African context be valued? Given his insightful argumentative exploration of his post-foundational approach with the focus on transversality and contextuality, an even more foundational dimension now comes to the fore that I would like to critically identify and explore. It is the dimension of affectivity, although mentioned ${ }^{17}$, but not developed in his viewpoint that comes from his strong emphasis on embodied personhood and the nature of experience as interpreted experience that in my opinion unavoidably necessitates the deepening and interdisciplinary broadening of his viewpoint on the nature of rationality.

17. See - for example - in his reference to the nature of transversality by stating the following: 'Transversal rationality thus emerges as a performative praxis where our following: 'Transversal rationality thus emerges as a performative praxis where our
multiple beliefs and practices, our habits of thought and attitudes, our prejudices and judgments, converge' (Van Huyssteen 2017:10). 


\section{Van Huyssteen's global positioning system for us as embodied persons within the South African context on theological reflection and rationality}

I find Van Huyssteen's suggested post-foundational approach directional, valuable and helpful ${ }^{18}$ to utilise as Global Positioning System (GPS) - that is, as theoretical mapping instrument for our South African territory regarding the contexts of our making (theological) sense in a responsible and credible manner of our religious experiences. I, however, rename the GPS ${ }^{19}$ as a 'God positing system', that is, on how we as embodied persons make sense ('mapping') of our religious experiences within our South African context ('territory'). In my opinion, some fundamental 'recalculating' will have to take place in the light (and darkness!) of a context deeply characterised by pluriversality ${ }^{20}$ and by Indigenous Knowledge Systems (IKS). ${ }^{21}$ My recalculating will consist of the refiguring of rationality as affective-cognitive in nature. Let me elaborate and explain.

If all experience - as Van Huyssteen argues - is to be understood as interpreted experience of embodied persons, and subsequently (contextually and transversally) unfolds with the personal commitment of the theologian intact in his postfoundational approach as a more holistic, embodied way to think about human rationality, the question can be asked whether he has taken our embodiment, and specifically, our biological make-up in our experiencing of the world, that is, in our making sense of the world - holistically and radically seriously enough. I would like to argue that his emphasis and understanding of 'cognitivity' in his unfolding of the nature of human rationality has to be complemented and broadened by affectivity (moods, emotions and feelings). Our making sense ${ }^{22}-$

18. Each one of the concepts have been chosen with very specific intent: Directive - to refer to the beginning of our journey with Van Huyssteen's response to Op weg met
die Teologie in which he has focused on the questions of truth, problem solving and progress; Valuable - to refer to the integrity and credibility of his proposed approach; Helpful - to refer to his explication of the dialogue between theology approach; Helpful - to refer to his explication of the dialogue between theology
and other disciplines in which transversal reasoning facilitates different, but equally legitimate ways of evaluating issues, problems, traditions, or even equally legitimate ways
disciplines themselves.

19.GPS is the acronym for Global Positioning System. The idea for GPS came from the use of networked ground-based radio navigation systems and from US scientists tracking in 1957 the launch of the Russian spacecraft Sputnik. I, however, use the acronym from my rephrasing of GPS as 'God positing system' in the sense of the very useful distinction by the American historian of religions Jonathan Zittell Smith He coined the now famous description and distinction of mapping and territory in his book Map is not Territory (1978).

20.With the concept pluriversality, the very specific character of the South African society is emphasised, namely that it is deeply determined and challenged by society is emphasised, namely that it is deeply determined and challenged by with regard to different forms of knowledge, see Conradie and Du Toit (2015:458ff.) For what they call 'knowledge forms', I use the concept pluriversality. The concept For what they call 'knowledge forms', I use the concept pluriversality. The concept
comes from decolonial theory. It wants to critically protest against contemporary comes from decolonial theory. It wants to critically protest against contemporary
Northern assumptions of the universal character of knowledge that ignores local and informal bodies of knowledge.

21.IKS refers to the understandings, skills and philosophies developed by societies with long histories of interaction with their natural surroundings. For rural and indigenous people, local knowledge informs decision-making about fundamenta aspects of day-to-day life (cf. Tharakan 2017).

22.The very recent work Touch (with the catchy subtitle: Recovering Our Most Vital Sense) by the Irish philosopher Kearney (2021) is the background to my formulation. $\mathrm{His}$ book is a fascinating philosophical exploration of the place and role of our senses in a world deeply characterised by digital technologies. Kearney (2021:9) explains that the term sense has three distinct meanings, namely as sensation, meaning and orientation. He insightfully remarks, 'These three meanings point to meaning and orientation. He insightfully remarks, 'These three meanings point to
the existence of a special intelligence of the body - a tactile sensibility that informs the existence of a special intelligence of the body- and this is the key word - of the world, is affective-cognitive in nature and therefore, we must broaden our understandings of the nature of rationality. Put differently, if Van Huyssteen argues in his post-foundational approach that we as embodied persons have good reasons (with our personal commitments intact) for holding on to our beliefs, does his 'reasons' actually / really include - in reference to the French philosophertheologian Pascal - the reasons of the heart ${ }^{23}$ of which reason does not even know? ${ }^{24}$ I would like to argue that affectivity represents the first and most basic (pre-reflexive) layer of our embodied engagement with reality and subsequently temporally-cerebrally evolves into a broader, reflexive deeper and sophisticated affective-cognitive dimension of being human that permeates our shared rational resources of reflection. ${ }^{25}$ In other words, in our embodied sense-making as rational agents of our lifeworlds that finds expression in language within our specific epistemic communities, I would like to metaphorically describe the integral connectedness as this way: in our spelling out of the meaningfulness of life, affectivity is represented by the consonants, and cognitivity by the vowels. The one cannot be without the other (read: does not make sense!) in our reasoning strategies in which we spell out the meaning and significance of our contextual experiences. A few directive remarks must suffice.

As embodied persons of 'flesh and blood', we as Homo sapiens ('wise person'), are the way that life knows life (and that reflectively find amongst others especially expression in sapientia, wisdom ${ }^{26}$ ). As anthropos ('upward gazer' $)^{27}$ we are (self-)conscious embodied persons with a

23. One of the most powerful metaphoric descriptions for one of the most significant dimensions of the quest of human life on its journey in search of and explicating meaning is in my opinion the heart. That is, the heart, as the seat of human life; the heart as the fountain of meaning, and of personhood. Just as the body physically cannot be alive without the heart as the organ that 'pumps blood', in the same metaphoric manner, we cannot talk about life if not 'pumped' by meaning in whatever cultural-philosophical and psycho-sociological manner it finds historicalcontextual reflective expression. And then not only meaning in reference to its cognitive dimension, but specifically adding - as heart - the affective dimension to meaning. The heart, as metaphoric descriptive term for the seat of life, thus of knowledge and affectivity, unleashes a cosmological-existential and poetic depth and width and height for reflection on all of life whether human or non-human (cf. Veldsman 2014:427-428).

24.In what follows, I re-interpret from an evolutionary epistemological perspective, the 19th century French philosopher-theologian Blaise Pascal's understanding of religious experience in his Pensées (1670) in which he states that we love God with our hearts, and that the heart has reasons of which reason is not even aware. See my earlier exposition of Pascal in Veldsman (2014).

25.The important question should immediately be asked, "Does this simply implies that the old traditional debate Rationality versus Irrationality (Emotionality) is reintroduced here with the chosen emphasis on the "heart'?" Yes, it is the very implication but for good reasons and the constructive integration of affectivity and cognitivity into contemporary science-theology discourses. Only by re-introducing the classic debate can - on the one hand - we critically address the very accusation of irrationality as misplaced and - on the other hand - to present us with a far of irrationality as misplaced and - on the other hand - to present us with a far
richer, deeper understanding of personhood. For an insightful and thorough richer, deeper understanding of personhood. For an insightful and thorough
discussion, see Is Faith Rational? (2006) by the Dutch philosopher of religion, discussion, see Is Faith Rational? (2006) by the Dutch philosopher of religion,
Wessel Stoker. He convincingly argues that to address the accusation of the irrationality of emotion, we have to refute those reductionistic viewpoints on irrationality of emotion, we have to refute those reductionistic viewpoints on
emotion that take emotions only to be an inner feeling or sensation that stands in emotion that take emotions only to
a physiological-causal relationship.

26.On the nature and role of wisdom from evolutionary and interdisciplinary perspectives, see the insightful publication Evolution of Wisdom: Major and Minor Keys (2018) edited by Agustín Fuentes and Celia Deane-Drummond.

27.In his discussion of the difference between Aristotle and Plato on the most pervasive and intelligent of the senses, the former privileging tactility (touch) whereas the latter privileges sight, Kearney (2021:34) makes the following important insightful statements. For Plato, sight was superior to touch, because it was closer to reason 'rising upward to supersensible ideas rather than descending, with touch, to dark feelings of flesh'. For Plato, man was the spectator of all existence. Plato cites the etymology of anthropos as 'upward gazer'. Kearney (2021:33) explains, citing Plato from Cratylus that for Plato 'anthropos implies that man not only sees but looks at what he sees, and hence 'anthropos implies that man not only sees but looks at what he sees, and hence
he alone of all animals is rightly called anthropos because he looks up at (anthropei) what he has seen'. 
number of body systems ${ }^{28}$ made up from groups of organs and tissues. They work together to perform important functions of and for the body. Within the context of my argument, I would like especially to emphasise the nervous, ${ }^{29}$ endocrine ${ }^{30}$ and integumentary/exocrine systems. ${ }^{31}$ These systems represent our first (pre-reflexive and pre-conceptual) embodied interpretative engagement of our affective experiencing of our lifeworlds. The Irish philosopher Kearney (2021:36), closely following Aristotle's understanding of touch to be the most universal of all our senses (in opposition to Plato's privileging of sight), captures it somatically beautifully in his own viewpoint on carnal hermeneutics and our first intelligence mediated by our skins, by stating as follows:

Our first wisdom comes through touch mediated by flesh where our sensing is already a reading of the world, interpreting things as this or that, constantly registering differences and distinctions. (p. 36)

And he also says:

Since all our senses involve touch, and since touch involves mediation, all our sensations can be said to involve semantic interpretations of some kind, understood as a primal orientation in time and space prior to theoretical consciousness. (p. 39)

Thus, for Kearney, following Aristotle, our first intelligence, that begins with the vulnerability of the skin that negotiates our primary feelings of things, is epidermal. ${ }^{32}$ He therefore concludes: 'In touching the world we are constantly prefiguring, refiguring and configuring our experience' (Kearney 2021:39). And where do we go as embodied persons from here in our reciprocal sense-making ${ }^{33}$ of our lifeworlds?

To be in touch with and to make sense of our lifeworlds flows into second and third layers of experiencing. From Layer 1,

28.There are different classifications for our body systems. They are mostly divided in 12 systems: circulatory and cardiovascular; digestive and excretory; endocrine 12 systems: circulatory and cardiovascular; digestive and excretory; endocrine;
integumentary and exocrine; immune and lymphatic; muscular; nervous; renal and urinary.

29.The nervous system (the brain, the brain stem and nerves) allows us to sense and respond to stimuli, such as light, sound, smell, and touch from ou environment. It also allows rapid communication of stimuli within our body. It collects and processes information from the senses via nerves and the brain and tells the muscles to contract to cause physical actions. This also includes our emotions and personality (cf. McLaughlin 2020:n.p.). The importance and constitutive role of the nervous system and cognition (the brain) in our human lives has given rise to the viewpoint that 'We are our brains'. It is a very popula and influential viewpoint in specifically Dutch neuroscientific literature. The Dutch theologian Gijs Dingemans has in his book Het brein geeft te denken (2012) very neatly critiqued the popular and influential rationalistic and reductionistic anthropological perspectives which suggest that 'we are our brains'.

30.The endocrine system consists of a number of tissues that send out chemical messages - called 'hormones' - to the rest of the body. Each of these messages has its own unique purpose, to which the body's other systems respond accordingly. The endocrine system allows the body to respond to environmental changes and to other types of survival changes (cf. McLaughlin 2020:n.p.).

31.The integumentary and exocrine system covers the body and regulates its exchange with the outside world. This includes the skin, hair, nails, sweat, and other glands that secrete substances onto the skin. The skin - a surprisingly complex materia and also the largest 'organ' in the body - keeps everything inside in, and it also keeps everything else out. Skin is our body's first line of defence against pathogens, harmful substances, injuries, and more (cf. McLaughlin 2020:n.p.).

32.For an exposition of the phenomenological revolution of 'back to the senses' - as Kearney calls it - within the work of philosophers such as Edmund Husserl and especially Maurice Merleau-Ponty, see Kearney (2021:45ff.).

33.Reciprocal refers to the statement by Kearney (2021:40) that if touch is something we do to the world, it is also something the world does to us. See his fascinating explanation of attraction and retraction in this regard (Kearney 2021:40). our experiencing flows through un/differentiated layered affectivity (Layer 2), represented by moods (undifferentiated), emotions and feelings (differentiated). Layer 2 flows into our reflections and actions (Layer 3), that is, our conscious theoretical sense-making and sensible living. A few explanatory remarks are necessary, especially with regard to the nature and role of emotions in Layer 2. It involves the contemporary and far-reaching debates on the emotional and rational brains on the bodyscape $e^{34}$ of contemporary discourses in the neurosciences, ${ }^{35}$ on human cognition and especially in evolutionary psychology on emotions (that - according to the Canadian philosopher Ronald de Sousa - represents the most important aspect of our mental lives with regard to the quality and meaning of our existence, and which subsequently make life worth living, or sometimes ending). ${ }^{36}$ What is of the utmost importance within interdisciplinary discourses on emotions is that our emotions are rooted in our biological nature. ${ }^{37}$ In his book Is Faith Rational? (2006), the Dutch philosopher of religion Wessel Stoker gives a clear and insightful explanation of emotions.

According to him, emotions have evolved over centuries from the basic instincts relating to mating, protection of territory, food, fight or flight and thus have an (evolutionary) cognitive core. They are communicated non-consciously and consciously by means of various different bodily systems and subsystems, consisting of neural networks and the blood network. He continues, stressing importantly that three components are distinguished in those theories on the origin of emotion that take their vantage point from their biological rootedness, namely the physiological and / or psychological state-of-mind component of the person experiencing the emotion, the object of the emotion and the relevant reasons for the emotion. Emotions thus have mental/cognitive and physical components. There is, however, more to affectivity than emotions. Following Strasser, Stoker (2006:178ff.) argues in his exposition of religious affectivity for a layered perspective of emotions. According to this viewpoint, ${ }^{38}$ mood represents the deepest, undifferentiated layer of affectivity. Mood lays bare our existence, that is, 'our thrownness in existence' (Stoker 2006:180). As 'pure feeling', it represents our 'finding of being in the world', or a specific 'felt state of mind, pure being-in-the-mood' (Strasser quoted by Stoker 2006:180). It represents a characteristic of being human that expresses our belonging to existence. Stoker (2006) remarks:

\section{In playful reference to landscape, I coin this term to define the constitutive importance of embodied personhood in our sense-making of the world. \\ 35.Two older but classic and very influential book publications are by the American neuroscientist Joseph LeDoux in his The Emotional Brain: The Mysterious Underpinnings of Emotional Life (1996) and the Portuguese-American neurobiologist Antonio Damasio in his The Feeling of What Happens (1999).}

36.See his very informative encyclopedic article on Emotion (De Sousa 2013).

37.In what follows, I make use of my earlier exposition of emotions in With Reasons of the Heart Before God. On Religious Experience From an Evolutionary-theological Perspective (Veldsman 2014).

38.Although it does not represent as Layer 2 in my exposition the deepest layer of affectivity! It does however represent a deep layer that is embedded in our first epidermal intelligence (Layer 1 ). 
Not only emotion but also mood influences our rational thought and our behaviour. The human being is a whole of bios, pathos and logos. Viewing affectivity as layered is an attempt to do justice to the different aspects of our humanness. (p. 179)

Mood (and thus our undifferentiated feelings of belonging) and emotions converge in our thoughts and actions in our hearts. Feeling internalises and personalises my thoughts / knowledge. And this all takes place in the heart! The heart unites and integrates what reason / knowledge separates and / or fragmentises (cf. Stoker 2006:184). This is what the affective-cognitive dimension of being human or personhood according to Stoker entails. At the same time they spell out how Pascal's 'reasons of the heart of which reason does not even know' can be evolutionary re-conceptualised from our biologically rootedness. In the words of the neuroscientist LeDoux (1996):

$[P]$ eople normally do things, all sorts of things for reasons they are not consciously aware of (because the behaviour is produced by brain systems that operate unconsciously) and that one of the main jobs of consciousness is to keep our life tied together into a coherent story, a self-concept. (p. 33)

Emotions, as evolutionary ingredient of the conscious 'keeping our life affectively-cognitively tied together into a coherent story' thus not only unavoidably shape our life(worlds), but is constitutive of the quality and meaning of our existence that indeed 'makes life worth living, or sometimes ending' (De Sousa 2013:1).

I conclude this section with a few remarks on Layer 3. It entails our theoretical sense-making and sensible living. The former, that is our theoretical sense-making, finds for me exceptional expression in Van Huyssteen post-foundational approach, but now within a broadened understanding of the nature and role of embodied persons as rational agents, specifically in the South African context characterised by pluriversality and IKS. It does not only opens our shared rational eyes, but simultaneously all our senses to the engagement within the conversation - constructively and critically - between different epistemic obligations. Different epistemic obligations that - as Van Huyssteen argued but now importantly re-formulated in the plural - self-critically ${ }^{39}$ point beyond the boundaries of our own discipline, our local communities, groups, or cultures, toward plausible forms of interdisciplinary dialogue. In this sense, we can embrace transversality as the celebration of pluriversality that - in the words of Van Huyssteen (2017):

$[P]$ romotes different, non-hierarchical but equally legitimate ways of viewing specific topics, problems, traditions, or disciplines, and creates the kind of space where different voices need not always be in contradiction, or in danger of assimilating one another, but are in fact dynamically interactive with one another. (p. 3)

And the very outcome of this embrace and the experiential flow?

39.To be consciously self-critical is of the utmost importance in this pluriversal context since it implies that our epistemic obligations are also to be subjected to critical dialogue.

\section{To care publicly for the truth and progress}

I return to the golden-thread-question posed by Van Huyssteen: Why would the theologian try to speak publicly? And who would care to hear his voice? I would like to answer Van Huyssteen tentatively as follows, making use of his sophisticated post-foundational GPS as Layer 3 and incorporating Layer 2 (affectivity) and Layer 1 (primal sensing) for the direction that I would like to pursue much further within our South African context. Truth has an embodied heart-beat in Africa (and for that matter, everywhere else!), Truth has embodied beauty. Truth nurtures embodied values and discloses multi-faceted embodied purposes. On the post-foundational journey from our first carnal epidermal experience to insight, from our shared (now broadened) rational resources, we responsibly have to have our (interdisciplinary) reflective fingers (or: be in touch with) on the pulse of progress. It's the very pulse of progress that contextually-practically (transversally) unfolds through methodological (Greek: meta + hodos = 'with this road') informed discernment. It is responsible theological discernment - within religious experience - that incarnates contextuality and transversality - as witness to Transcendence, As reflective witness to Transcendence it is realised affectivecognitively as the sensing of God's voice here and now that echoes from our respective culturally pasts as directives for the future. That is, God's incarnated voice as the sound of sense-making in our interdisciplinary reflective processes in search for truth and progress. That is why we truthfully and wholeheartedly care to hear theologians' public voices. I feelingly know and knowingly feel as part of our epistemic communities as 'upward gazing embodied sensemakers' that it is the less travelled road to take now and pursue even further and deeper. ${ }^{40}$

\section{Acknowledgements Competing interests}

The author declares that he has no financial or personal relationships that may have inappropriately influenced him in writing this article.

\section{Author's contributions}

D.V. is the sole author of this article.

\section{Ethical considerations}

This article followed all ethical standards for research without direct contact with human or animal subjects.

\section{Funding information}

This research received no specific grant from any funding agency in the public, commercial or not-for-profit sectors.

40.My answer to Van Huyssteen's but also to Richard Kearney's question: So is it not time to return to our senses? To get back in touch with ourselves and with others, reinhabiting our skins, reclaiming our bodies and emotions? (Kearney 2021:6) 


\section{Data availability}

Data sharing is not applicable to this article as no new data were created or analysed in this study.

\section{Disclaimer}

The views and opinions expressed in this article are those of the author and do not necessarily reflect the official policy or position of any affiliated agency of the author.

\section{References}

Conradie, E. \& Du Toit, C., 2015, 'Knowledge, values, and beliefs in the South African context since 1948: An overview', Zygon 50(2), 455-479. https://doi.org/10.1111/ zygo.12167

De Sousa, R., 2013, 'Emotion', in E.N. Zalta (ed.), The Stanford Encyclopedia of Philosophy, viewed 31 March 2021, from http://plato.stanford.edu/archives/ spr2014/entries/emotion.

Heyns, J. \& Jonker, W., 1977, Op weg met die Teologie, 2nd edn., NG Kerkboekhandel, Pretoria.

Kearney, R., 2021, Touch: Recovering our most vital sense, Columbia University Press, New York, NY.

König, A., 1978, 'Opmerkinge oor Van Huyssteen: Teologie en metode', Koers 43(4), 399-406. https://doi.org/10.4102/koers.v43i4.1174
LeDoux, J., 1996, The emotional brain: The mysterious underpinnings of emotional life, Simon \& Schuster Paperbacks, New York, NY.

McLaughlin, K., 2020, Body systems, viewed 31 March 2021, from https:// biologydictionary.net/body-systems/.

Stoker, W., 2006, Is faith rational?, Peters, Leuven.

Tharakan, J., 2017, Indigenous knowledge systems for appropriate technology development, viewed 31 March 2021, from https://wwwintechopen com/books/ indigenous-people/indigenous-knowledge-systems-for-appropriate-technologydevelopment.

Van Huyssteen, J.W.V., 1978a, 'Teologie en metode', Koers 43(4), 377-398. https://doi. org/10.4102/koers.v43i4.1172

Van Huyssteen, J.W.V., 1978b, 'Antwoord aan professor Adrio König', Koers 43(4), 407. https://doi.org/10.4102/koers.v43i4.1175

Van Huyssteen, J.W.V., 1986, Teologie as kritiese geloofsverantwoording, RGN, Pretoria.

Van Huyssteen, J.W.C., 1989, Theology and the justification of faith, Wentzel Eerdmans, Grand Rapids, MI.

Van Huyssteen, 2017, "Is there any hope for "truth" and "progress" in theological Wentzel thinking today?', Verbum et Ecclesia 38(1), 1-10. https://doi.org/10.4102/ ve.v38i1.1792

Veldsman, D., 2008, 'Telling the Christian story with interdisciplinary integrity from an evolutionary epistemological perspective: On Wentzel van Huyssteen', Scriptura 98, 222-230. https://doi.org/10.7833/98-0-707

Veldsman, D., 2014, 'With reasons of the heart before God: On religious experience from an evolutionary-theological perspective', Nederduitse Gereformeerde Teologiese Tydskrif 55(1-2), 425-441. https://doi.org/10.5952/55-1-2-534 